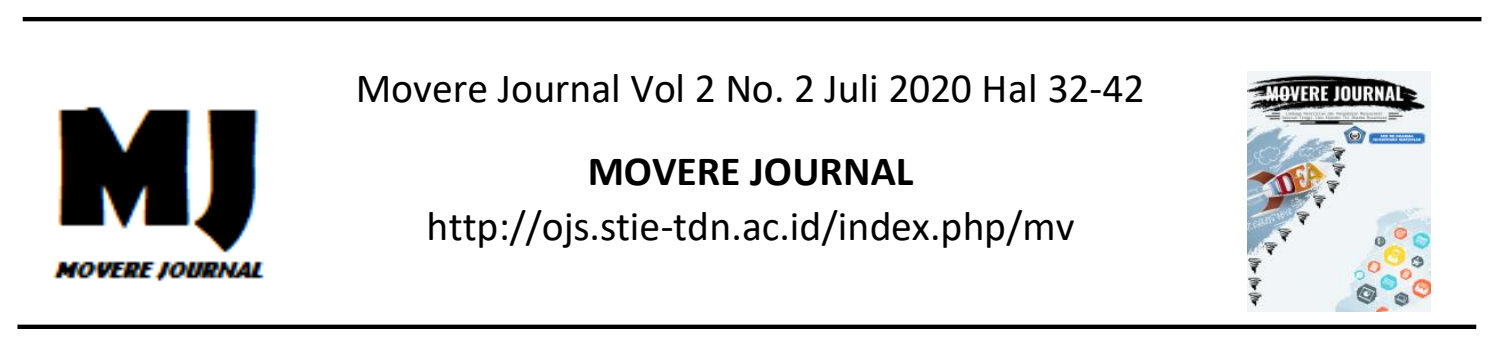

\title{
ANALISIS KINERJA KEUANGAN PADA BANK PERKREDITAN RAKYAT HASAMITRA CABANG MAKASSAR (STUDI KASUS : BANK PERKREDITAN RAKYAT HASAMITRA)
}

\author{
Ira Parwaty Rany, Andi Nirwana Nur, Jayadi \\ Fakultas Ekonomi dan Bisnis Universitas Muslim Indonesia
}

\begin{abstract}
Abstrak: Penelitian ini bertujuan untuk mengetahui kondisi kesehatan keuangan bank dan untuk mengetahui perkembangan kesehatan keuangan bank pada Bank Perkreditan Hasamitra Cabang Makassar dari tahun 2014-2016.Subjek daiam penelitian ini adalah pimpinan Bank Perkreditan Rakyat Hasamitra Cabang Makassar. Objek penelitian adalah menganalisa laporan keuangan pada Bank Perkreditan Rakyat Hasamitra Cabang Makassar selama periode 2014- 2016. Jenis penelitian ini adalah penelitian deskriptif dengan data yang digunakan adalah laporan keuangan. Teknik pengumpulan data adalah dokumentasi. Analisis yang digunakan adalah analisis CAMEL yang digunakan untuk menilai tingkat kesehatan keuangan bank berdasarkan permodalan, kualitas aktiva produktif (KAP), manajemen, rentabilitas, dan likuiditas.
\end{abstract}

Kata kunci: Analisis CAMEL, Kinerja Keuangan

\begin{abstract}
PENDAHULUAN
Peranan perbankan dalam suatu bisnis sangat menentukan maju mundurnya perekonomian suatu bangsa, hal ini mengingat perbankan merupakan motor penggerak sekaligus katalisator dalam usaha untuk mempercepat laju perkembangan dunia usaha.

Sebagai bank dalam usaha
untuk menghimpun dana dari masyarakat dalam bentuk simpanan dan menyalurkannya kepada masyarakat dalam bentuk kredit atau bentuk-bentuk lainnya dalam rangka meningkatkan taraf hidup rakyat

banyak di tuntut meningkatkan leane
\end{abstract}

dan profesionalisasi dalam hal pengelolaan seluruh asset yang akan dimilikinya.

Salah satu sumber utama pendapatan perbankan adalah bersumber pada pendapatan hasil bagi bunga dan pemberian kredit pada masyarakat, disamping pendapatan melalui usaha-usaha di bidang jasajasa lainnya. Dengan demikian kegiatan bank perkreditan dalam usaha mencari keuntungan ini berupa pengumpulan dana yang bermacammacam sifatnya (volume dan jangka waktunya) untuk selanjutnya ditanamkan dalam surat-surat berharga

(C) 2020 STIE TDN. All rights reserved

Corresponding Author: 
serta pemberian kredit untuk memperoleh pendapatan.

Dalam kaitannya dengan sifat pokok kegiatan bank penkreditan mempunyai fungsi yakni pengumpulan dana, pembiayaan, peningkatan faedah dari dan masyarakat (dengan memindahkan dari pihak yang kelebihan dana yang mungkin kurang faedah, kepada pihak yang membutuhkan), serta menanggung resiko. Oleh karena itu, keberhasilan suatu usaha bank sangat ditentukan oleh kinerja bank yang bersangkutan dalam mengelolah asset dan kredit yang disalurkan kepada masyarakat. Akan tetapi kegiatan pemberian kredit kepada masyarakat merupakan suatu jenis usaha yang sangat besar resikonya.

Kegiatan pemberian kredit kepada masyarakat apabila tidak dikelolah dengan professional akan berdampak pada kerugian sangat signifikan terhadap tingkat usaha dan profitabilitas serta tingkat pertumbuhan asset perbankan. Dengan pengelolaan yang baik dan ditunjang oleh kemampuan manajerial yang handal, maka segala kemungkinan yang terjadi dalam pemberian kredit pada masyarakat dapat terelimisir dengan baik.

Kesehatan atau kondisi keuangan bank dan non keuangan bank merupakan kepentingan semua pihak terkait, baik pemilik, pengelola (manajemen) bank, masyarakat pengguna jasa bank, Bank Indonesia selaku otoritas pengawasan bank, dan pihak lainnya. Kondisi keuangan bankbank tersebut dapat digunakan oleh pihak-pihak tersebut untuk mengevaluasi kinerja bank dalam menetapkan prinsip kehati-hatian, kepatuhan terhadap ketentuan yang berlaku dan manajemen resiko.
Tingkat kesehatan keuangan bank bank adalah hasil penilaian kualitatif atas berbagai aspek yang berpengaruh terhadap kondisi atau kinerja suatu bank melalui Penilaian Kuantitatif dan Penilaian Kualitatif terhadap faktor- faktor Capital, Asset Quality, Management, Earning, dan Liquidity yangdisingkat CAMEL.

Perkembangan industri perbankan, terutama produk dan jasa yang semakin kompleks dan beragam akan meningkatkan eksposur risiko yang dihadapi bank.

Perubahan eksposur risiko bank dan penerapan manajemen risiko akan mempengaruhi profil risiko bank yang selanjutnya berakibat pada kondisi bank secara keseluruhan.

Perkembangan metodologi penilaian kondisi keuangan bank-bank senantiasa bersifat dinamis sehingga sistem penilaian tingkat kesehatan keuangan bank harus diatur kembali agar lebih mencerminkan kondisi bank saat ini dan di waktu yang akan datang.

Pada umunya bank dikenal sebagai lembaga keuangan yang kegiatan utamanya menerima Simpanan, Giro, Tabungan dan Deposito. Bank dikenal juga sebagai tempat untuk meminjam uang (kredit) bagi pihak yang kekurangan dana (defisit unit). Di samping itu bank juga dikenal sebagai tempat penyimpanan uang bagi pihak yang kelebihan dana (surplus unit), tetapi tidak hanya itu saja bank juga memiliki fungsi-fungsi lain yang hari ke hari semakin meluas.

Terlebih lagi dikarenakan oleh kemajuan perekonomian dan semakin tingginya tingkat kegiatan ekonomi, telah mendorong bank untuk menciptakan produk dan layanan yang sifatnya memberikan kepuasan dan kemudahan- kemudahan untuk para nasabahnya, misalnya menyediakan

(C) 2020 STIE TDN. All rights reserved 
mekanisme dan alat pembayaran yang lebih efisien dalam kegiatan ekonomi, serta memberikan pelayanan penyimpanan untuk barang-barang berharga dan penawaran jasa-jasa keuangan lainnya. Tentu saja keberadaannya sangat mempermudah dan memperlancar seluruh aktivitas ekonomi masyarakat dan menempatkan bank menjadi sebuah lembaga keuangan yang sangat strategis.

Subjek penelitian yang akan dilakukan hanya pada Bank Perkreditan Rakyat. Ditengah-tengah persaingan bank dalam mempertahankan eksistensi dan kepercayaan dari masyarakat yang menjadi konsumennya dan sebagai ujung tombak perbankan di pedesaan, kinerja Bank Perkreditan Rakyat mampu terus bertahan dan menjadi pilihan masyarakat.

Dalam perekonomian Indonesia, salah satu tujuan pembangunan di Indonesia adalah untuk meningkatkan taraf hidup masyarakat melalui pembangunan ekonomi. Hal ini dinyatakan dengan jelas dalam GBHN bahwa peningkatan taraf hidup dan kesejahteraan yang adil dan merata, itu hanya dapat dicapai jika ada peningkatan pembangunan ekonomi.

Bank Perkreditan Rakyat sebagai salah satu bentuk lembaga/ perbankan di Indonesia yang tidak luput dari maslah-masalah yang ditimbulkan dari adanya kirisis ekonomi. BPR dituntut untuk tetap bertahan hidup dan berkembang di dalam mencapai tujuannya. Untuk mencapai hasil operasionalnya yang memuaskan, salah satu cara untuk mengukur apakah dalam pengelolaan usaha BPR telah melakukan sesuai dengan asas-asas perbankan yang sehat dan sesuai dengan ketentuan-ketentuan yang berlaku, dapat dilihat dari tingkat kesehatan keuangan bank BPR yang bersangkutan. Tingkat kesehatan keuangan bank bank dapat diartikan sebagai kemampuan suatu bank untuk melaksanakan kegiatan operasional perbankan secara normal dan mampu memenuhi suatu kewajiban dengan cara-cara yang sesuai peraturan perbankan yang berlaku.

Berdasarkan Surat Edaran Bank indonesia No. 30/3/UPPB tanggal 30 April 1997 dan No. 30/12/KEP/DIR tentang cara penilaian tingkat kesehatan keuangan bank bank dari berbagai aspek, penentuan tingkat kesehatan keuangan bank bank menggunakan lima kelompok faktor yaitu permodalan, kualitas aktiva prioduktif, manajemen, rentabilitas, dan likuiditas atau lebih dikenal dengan sebutan CAMEL dalam mengukur skala operasi dan struktur permodalannya. Pada analisis CAMEL tersebut ada kriteria yang telah ditentukan oleh Bank Indonesia adalah tentang seberapa besar persentase kinerja keuangan yang memenuhi persyaratan bank tersebut untuk dinyatakan sehat, serta tidak membahayakan/merugikan pihakpihak yang berkepentingan.

Analisis

CAMEL

dikuantifikasikan sebagai aspek penilaian yang merupakan perhitungan rasio keuangan. Oleh karena itu rasio keuangan bermanfaat dalam menilai tingkat kesehatan keuangan bank bank. Semakin besar skala operasi bank yang diukur dengan total asset dan semakin tinggi jumlah modal dari bank tersebut diharapkan kinerja operasinya semakin baik.

Keberhasilan suatu usaha Bank Perkreditan Rakyat dapat dicerminkan dari peranannya terhadap kebijakan 
ekonomi rakyat. Untuk mengetahui keberhasilan Bank Perkreditan Rakyat perlu diadakannya penilaian terhadap tingkat kesehatan keuangan bank Bank Perkreditan Rakyat secara menyeluruh. Hasil dari rasio keuangan digunakan untuk menilai tingkat kesehatan keuangan bank bank dalam suatu periode apakah mencapai target seperti yang telah ditetapkan. Dari penilaian tingkat kesehatan keuangan bank bank yang dihasilkan dapat dijadikan sebagai evaluasi hal-hal yang perlu dilakukan ke depan agar kinerja manajemen dapat ditingkatkan atau dipertahankan sesuai target perbankan.

Untuk mengukur kemampuan manajerial perbankan dalam mengelolah seluruh asset perbankan maka dapat dilihat dari sisi perkembangan dan pertumbuhan asset, penghimpunan dan pihak ketiga (DPK) dan pertumbuhan kredit serta peningkatan laba dari tahun ke tahun. Dengan meneliti dan membahas masalah perkembangan keuangan perusahaan setiap periode, maka diharapkan dapat diketahui bagaimana pengambilan keputusan perusahaan khususnya di bidang keuangan, yang sebaiknya ditempuh agar kelangsungan hidup perusahaan dapat dipertahankan untuk mendapatkan tujuan-tujuannya serta dapat bersaing dengan perusahaan lain. Berdasarkan latar belakang masalah tersebut diatas, maka dirumuskan masalah pokok sebagai berikut "Bagaimanakah Kinerja Keuangan pada Bank Perkreditan Rakyat Hasamitra Cabang Makassar mulai tahun 2014-2016".

\section{METODE PENELITIAN}

Untuk memperoleh data yang diperlukan dalam penelitian ini, maka penulis mengambil data pada perusahaan Bank Perkreditan Rakyat
Hasamitra Cabang Makassar Jl. Cokroaminoto No. 212 Makassar. Adapun waktu penelitian ini adalah dari bulan Agustus sampai dengan bulan September 2017.

Metode pengumpulan data yang digunakan untuk mengumpulkan data penelitian ini adalah dokumentasi. Dokumentasi yaitu teknik pengumpulan data yang dilakukan dengan mengumpulkan sejumlah dokumen perusahaanyang relevan dengan penelitian ini.

\section{Jenis dan Sumber Data Jenis Data}

Adapun jenis data yang akan digunakan dalam penelitian ini adalah:

1. Data Kualitatif yaitu data yang tidak dapat dihitung atau Data yang bukan berupa angka-angka.

2. Data Kuantitatif yaitu data yang diperoleh pada perusahaan dalam bentuk angka-angka yang berkaitan dengan perkembangan kinerjakeuangan Bank Hasamitra Cabang Makassar.

\section{Sumber Data}

Sumber data dari penelitian ini adalah data sekunder yaitu data yang diperoleh dari laporan tertulis yang ada hubungannya dengan perusahaan atau sumber-sumber tertulis lainnya yang terkait langsung dengan pokok pembahasan penelitian ini.

\section{Metode Analisis}

Untuk mempermudah pembahasan dan menguji hipotesis yang diajukan dalam penulisan proposal ini, maka penulis menggunakan Metode Camels adalah suatu metode untuk menggambarkan tingkat kinerja Bank Hasamitra Cabang Makassar yang meliputi aspek Capital, Asset, Manajemen, Earning, dan Liquidity untuk tahun 2014-2016, 


\section{Permodalan (Capital)}

$\mathrm{CAR}=\frac{\text { Modal Sendiri }}{\text { Aktiva Tertimbang }} \mathrm{X} 100 \%$

CAR (Capital Adequacy Ratio) merupakan rasio permodalan yang menunjukkan kemampuan bank dalam menyediakan dana untuk keperluan pengembangan usaha serta menampung kemungkinan risiko kerugian yang di akibatkan dalam operasional bank. Semakin besar rasio tersebut akan semakin baik posisi modal. CAR adalah rasio yang memperlihatkan seberapa besar jumlah seluruh aktiva bank yang mengandung resiko(kredit, penyertaan, surat berharga, tagihan pada bank lain) ikut di biayaidari modal sendiri di samping memperoleh dana-dana dari sumbersumber luar bank.

\section{Kualitas Asset (Asset Quality)}

$\mathrm{KAP}=\frac{\text { Aktiva produktif yang diklasifikasikan }}{\text { Total Aktiva Produktif }} \times 100 \%$

KAP (Kualitas Asset Produktif Principel) yaitu berfungsi untuk pengawasan mengandung arti bahwa anggaran menjadi pedoman untuk menilai kegiatan penyelenggaraan sesuai dengan ketentuan yang ditetapkan.

\section{Manajemen (Management)}

$\mathrm{NPM}=\frac{\text { Laba Bersih }}{\text { Laba Operasional }} \times 100 \%$

NPM (Non Profit Margin) ialah rasio yang digunakan untuk menunjukkan kemampuan perusahaan dalam menghasilkan laba bersih.

\section{Rentabilitas (Earning)}

$\mathrm{ROA}=\frac{\text { Laba Bersih Sebelum Pajak }}{\text { Total Aktiva }} \mathrm{X}$

$100 \%$

ROA (Return On Asset) adalah salah satu bentuk dari rasio profitabilitas untuk mengukur kemampuan perusahaan dalam menghasiikan laba dengan menggunakan total aktiva yang ada dan setelah biaya-biaya modal (biaya yang digunakan mendanai aktiva) dikeluarkan dari analisis.

$\mathrm{BOPO}=\frac{\text { Beban Operasional }}{\text { Pendapatan Operasional }} \mathrm{X}$

$100 \%$

BOPO (Rasio Biaya Operasional terhadap Pendapatan Operasional) adalah kelompok rasio yang mengukur efesiensi dan efektivitas operasional suatu perusahaan dengan membandingkan satu tahap dengan tahap lainnya.

\section{Likuiditas (Liquidity) Jumlah Kredit Yang Diberikan}

$L D R=\frac{\text { jumlah kredityang diberikan }}{\text { Dana Pihak Ketiga }} \times 100 \%$

LDR (Loan To Deposit Ratio) adalah rasio keuangan perusahaan perbankan yang berhubungan dengan aspek likuiditas, LDR adalah suatu pengukuran yang menunjukkan deposito berjangka, giro, tabungan, dan lain-lain yang digunakan dalam memenuhi permohonan pinjaman nasabahnya.

\section{HASIL PENELITIAN DAN PEMBAHASAN}

\section{Hasil Penelitian}

(C) 2020 STIE TDN. All rights reserved

\section{Corresponding Author:}




\section{Faktor Permodalan}

Salah satu faktor yang mempengaruhi kinerja keuangan khususnya bagi setiap perusahahaan adalah faktor permodalan. Alasannya karena tanpa ditunjang oleh adanya faktor permodalan maka setiap perusahaan tidak mampu beroperasi. Oleh karena itu maka dapatlah dikatakan bahwa aspek permodalan memegang peranan yang penting. Pentingnya aspek permodalan, maka salah satu rasio yang digunakan dalam mengukur kecukupan modal adalah rasio CAR (Capital Adequacy Ratio). Rasio ini merupakan salah satu cara yang digunakan dalam menghitung apakah modal yang ada pada suatu bank telah mencukupi. Sehingga rasio CAR dapat dihitung dengan menggunakan rumus sebagai berikut :

$$
\text { CAR }=\frac{\text { Modal Sendiri }}{\text { Aktiva Tertimbang }} \times 100 \%
$$

Kemudian perlu ditambahkan bahwa menurut ketentuan Bank Indonesia yang dinyatakan bahwa bank yang dikategorikan sehat jika memiliki CAR paling sedikit sebesar $8 \%$. Berdasarkan hasil perhitungan nilai kredit CAR dalam tiga tahun terakhir (tahun 2014 s/d tahun 2016) maka dapat disajikan melalui tabel berikut ini:

Tabel. 1

Besarnya Nilai Kredit Car Bank Perkreditan Rakyat Hasamitra Cabang Makassar Tahun 2014 s/d Tahun 2016

\begin{tabular}{|c|c|c|c|}
\hline Tahun & Ratio CAR & Nilai Kredit & Maksimum \\
\hline 2014 & $95,55 \%$ & $10,5155 \%$ & 100 \\
\hline 2015 & $18,24 \%$ & $3,824 \%$ & 100 \\
\hline 2016 & $17,84 \%$ & $2,784 \%$ & 100 \\
\hline
\end{tabular}

Sumber: Hasil Olahan Data

Berdasarkan tabel. 1 yakni ratio

CAR dan nilai kredit, yang menunjukan bahwa dalam tahun 2014 rasio CAR menurun sebesar 9,05\% sehingga menyebabkan nilai kredit menurun, sedangkan dalam tahun 2016 masih mengalami penurunan sebesar $6,40 \%$, sehingga berdampak pada nilai kredit mengalami penurunan. Menurut ketentuan dari Bank Indonesia nilai maksimum 100, sehingga nilai kredit rasio CAMEL untuk tiga tahun ditentukan sebesar 100.

\section{Faktor Kualitas (Asset)}

Dalam melakukan kualitas asset, jenis rasio yang digunakan adalahratio KAP. Ratio ini merupakan perbandingan antara jurnlah aktiva produktif yang diklasifikasikan dengan total aktiva produktif.

Besarnya ratio KAP dapat dihitung dengan menggunakan rumus:

$$
\mathrm{KAP}=\frac{\text { Aktiva Produktif yang Diklasifikasikan }}{\text { Total Aktiva Produktif }} \quad 100 \%
$$

a) Tahun 2014

Besarnya ratio KAP untuk tahun 2014 pada Bank Perkreditan
Rakyat Hasamitra Cabang Makassar dapat dihitung sebagai berikut:

$$
\mathrm{KAP}=23.860 \times 100 \%=2,54 \%
$$


938.173

b) Tahun 2015

Besarnya rasio KAP untuk tahun 2015 Bank Perkreditan Rakyat

Hasamitra Cabang Makassar dapat dihitung sebagai berikut:

$$
\mathrm{KAP}=\begin{gathered}
12.422 \\
359.177
\end{gathered} \times 100 \%=3,45 \%
$$

c) Tahun 2016

Besarnya rasio KAP untuk tahun 2016 Bank Perkreditan Rakyat

Hasamitra Cabang Makassar dapat dihitung sebagai berikut:

$$
\mathrm{KAP}=\begin{gathered}
90.484 \\
406.187
\end{gathered} \times 100 \%=2,22 \%
$$

Untuk lebih jelas akan untuk tahun $2014 \mathrm{~s} / \mathrm{d}$ tahun. 2016 yang disajikan hasil perhitungan rasio KAP dapat disajikan pada tabel berikut ini:

Tabel. 2

Hasil Perhitungan Rasio KAP Bank Perkreditan Rakyat Hasamitra

Cabang Makassar Tahun 2014 s/d Tahun 2016

\begin{tabular}{|c|c|c|}
\hline Tahun & Rasio KAP & Pertumbuhan (\%) \\
\hline 2014 & 2,54 & - \\
\hline 2015 & 3,45 & 0,91 \\
\hline 2016 & 2,22 & $-1,23$ \\
\hline
\end{tabular}

Sumber: Hasil Olahan Data

Dari tabel.2 hasil perhitungan rasio KAP untuk tiga tahun (tahun 2014 s/d tahun 2016) yang menunjukan bahwa untuk tahun 2015 rasio KAP meningkat sebesar 0,91\% yang disebabkan karena adanya peningkatan karena adanya kenalkan aktiva produktif, sedangkan tahun 2016 KAP menurun sebesar $-1,23 \%$.

Kesimpulan berdasarkan hasil penelitian, pada tahun 2014 s/d tahun 2016 menunjukan hasil nilai kredit mengalami penurunan, namun pada tahun 2016 mengalami peningkatan.

\section{Faktor Manajemen}

Kualitas manajemen dapat dinilai dari kualitas manusianya dalam bekerja. Untuk menilai kesehatan bank dalam aspek manajemen, biasanya dilakukan melaiui kuesioner yang ditujukan bagi pihak manajemen bank,

akan tetapi pengisian tersebut sulit dilakukan karena akan terkait dengan unsur kerahasian bank. Oleh sebab itu dalam penelitian ini aspek manajemen diproyeksikan dengan ratio net profit margin (Rhomy, 2011). Kemudian ratio NPM dapat dihitung dengan menggunakan rumus: 


$$
\mathrm{NPM}=\frac{\text { Laba Bersih }}{\text { Laba Operasional }} \times 100 \%
$$

\section{Tabel 3}

Hasil Perhitungan NPM Bank Perkreditan Rakyat Hasamitra Cabang Makassar Tahun 2014 s/d 2016

\begin{tabular}{|c|c|c|}
\hline Tahun & NPM & Pertumbuhan \\
\hline 2014 & 61,26 & - \\
\hline 2015 & 73,42 & 12,16 \\
\hline 2016 & 79,45 & $-6,03$ \\
\hline
\end{tabular}

Sumber : Hasil Olahan Data

Berdasarkan tabel. 3 yakni hasil perhitungan NPM yang menunjukan bahwa untuk tahun 2015 NPM meningkat yang disebabkan karena adanya peningkatan laba bersih, sedangkan tahun 2016 NPM meningkat karena adanya peningkatan pada laba operasional.

\section{Faktor Rentabilitas}

Aspek likuiditas digunakan dalam mengukur kemampuan bank dalam membayar semua hutanghutangnya terutama hutang jangkapendek. Oleh karena itulah akan disajikan ratio likuiditas yaitu sebagai berikut:

\section{a. Return On Asset (ROA)}

Return on asset digunakan uniuk mengukur kemapuan manajemen bank dalam memperoleh keuangan (laba bersih sebelum pajak). Samakin besar ROA, semakin besar pula tingkat keuntungan yang dicapai bank, sehingga kemampuan suatu bank dalam suatu kondisi bermasalah semakin kecil. Besarnya nilai ROA dapat dihitung dengan menggunakan rumus sebagai berikut:

$$
\begin{aligned}
& \text { Laba Bersih } \\
& \text { ROA }=\frac{\text { Sebelum Pajak }}{\text { Total Aktiva }} \times 100 \%
\end{aligned}
$$

Tabel. 4

Besarnya Nilai Kredit Rasio ROA Bank Perkreditan Rakyat Hasamitra Cabang Makassar Tahun 2014 s/d Tahun 2016

\begin{tabular}{|c|c|c|}
\hline Tahun & Nilai Kredit & Maksimum \\
\hline 2014 & 80 & 100 \\
\hline 2015 & 74,66 & 100 \\
\hline 201.6 & 88 & 100 \\
\hline
\end{tabular}

Sumber: Hasil Olahan Data

Berdasarkan tabel. 4 yang menunjukan bahwa nilai kredit untuk tahun 2014 s/d tahun 2016 meningkat yang disebabkan karena adanya kenaikan laba bersih sebelum pajak, namun pada tahun 2015 nilai kredit mengalami penur-anan yang tidak terlalu signifikan karena pada tahun 2016 kembali meningkat.

\section{b. BOPO}

Ratio BOPO digunakan mengukur tingkat efisiensi dan kemampuan bank dalam melakukan kegiatan operasinya, Ratio BOPO diperoleh dengan cara membagi biaya 
operasional, dengan menggunakan rumus :

Pendapatan Operasional

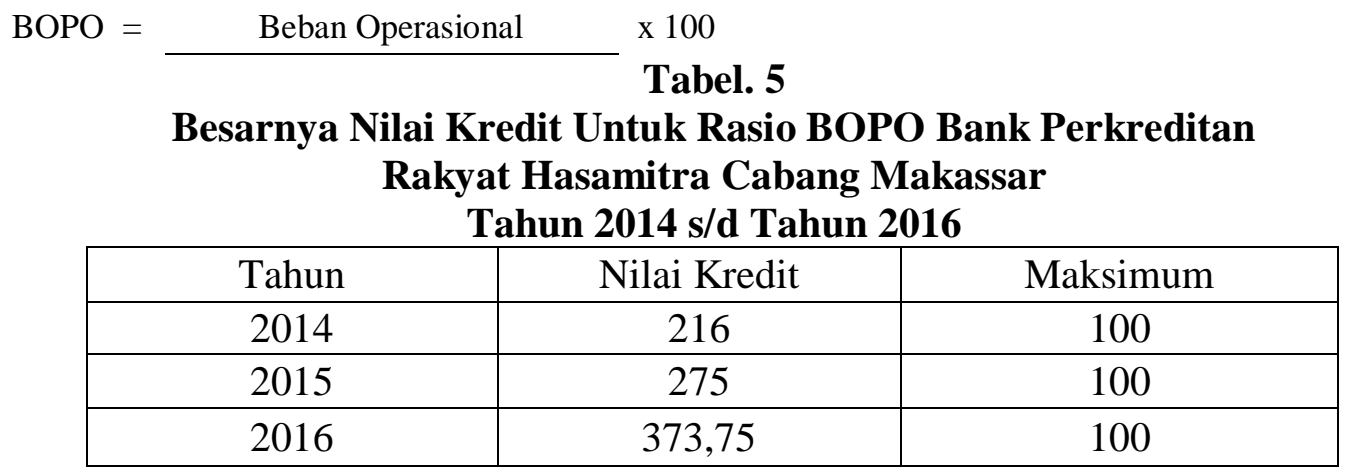

Sumber: Hasil Olahan Data

Berdasarkan tabel. 5 diatas hasil perhitungan nilai kredit pada tahun 2014 mengalami penurunan, namun pada tahun 2016 nilai kredit ratio BOPO kembali meningkat.

\section{Faktor Likuiditas}

Analisis terhadap komponen likuiditas merupakan analisis yang dilakukan terhadap kemampuan bank dalam memenuhi kewajiban-kewajiban jangka pendeknya atau kewajiban yang sudah jatuh tempo.
Berdasarkan ketentuan yang sudah dikeluarkan oleh Bank Indonesia, komponen likuiditas bank diukur berdasarkan Loan to Deposit Ratio (LDR).

$$
\mathrm{LDR}=\frac{\begin{array}{c}
\text { Jumlah Kredit yang } \\
\text { diberikan }
\end{array}}{\text { Dana Pihak Ketiga }} \times 100 \%
$$

Tabel. 6

Besarnya Nilai Kredit untuk Rasio LDR Bank Perkreditan Rakyat Hasamitra Cabang Makassar Tahun 2013 s/d Tahun 2016

\begin{tabular}{|c|c|c|}
\hline Tahun & Nilai Kredit & Maksimum \\
\hline 2014 & 30,72 & 100 \\
\hline 2015 & 39,46 & 100 \\
\hline 2016 & 39,99 & 100 \\
\hline
\end{tabular}

Sumber: Hasil Olahan Data

Dari tabel. 6 diketahui bahwa selama kurun waktu 2014 hingga tahun 2016, Bank Perkreditan Rakyat Hasamitra Cabang Makassar masih dapat mere rtahankan nilai ratio LDRnya pada nilai maksimal yaitu 100 , untuk tetap dikategorikan bank yang sehat. Ini berarti bahwa, dalam kurun waktu tersebut, Bank Perkreditan Rakyat Hasamitra. Cabang Makassar mampu untuk memberikann nasabahnya dan memiliki kemampuan dalam membayar semua utangutangnya terutama dalam bentuk simpanan Tahungan, giro, dan deposito pada ditagih, serta dapat memenuhi (C) 2020 STIE TDN. All rights reserved

Corresponding Author: 
semua permohanan kredit yang layak untuk disetujui.

\section{Analisis \\ Penilaian \\ Tingkat}

\section{Kesehatan Kerja}

Setelah dilakukan perhitungan rasio kinerja keuangan pada Bank Perkreditan Rakyat Hasamitra Cabang Makassar maka selanjutnya akan dilakukan penilaian kesehatan keuangan dengan menggunakan rumus CAMEL. Hal ini dimaksudkan untuk dapat menilai apakah kinerja keuangar. Bank dapat dikategorikan sehat.

Menurut ketentuan Bank Indonesia, bahwa kategori sehat dapat dikelompokkan dalam empat kelompok yang dilihat pada tabel berikut ini:

Tabel. 7

TINGKAT KESEHATAN BANK MENURUT CAMEL

\begin{tabular}{|c|c|}
\hline Nilai Kredit CAMEL & Predikat \\
\hline $81 \%-100 \%$ & Sehat \\
$66 \%-<81 \%$ & Cukup Sehat \\
$51 \%-<66 \%$ & Kurang Sehat \\
$0 \%-<51 \%$ & Tidak Sehat \\
\hline
\end{tabular}

Sumber: Bank Indonesia

Dalam hubungannya dengan uraian tersebut diatas, maka akan dilakukan perhitungan bobot dengan menggunakan metode CAMEL untuk tahun 2014 s/d tahun 2016 yang dapat dilihat melalui tabel berikut ini:

Tabel. 8

Hasil Evaluasi Kinerja Keuangan Dengan METODE CAMEL Bank Perkreditan Rakyat Hasamitra Cabang Makassar Tahun 2014 s/d Tahun 2016

\begin{tabular}{|c|l|l|c|c|c|c|}
\hline Tahun & \multicolumn{1}{|c|}{$\begin{array}{c}\text { Faktor } \\
\text { Penilaian }\end{array}$} & $\begin{array}{c}\text { Indikator } \\
\text { Kinerja }\end{array}$ & $\begin{array}{c}\text { Nilai } \\
\text { Rasio }\end{array}$ & $\begin{array}{c}\text { Nilai } \\
\text { Kredit }\end{array}$ & $\begin{array}{c}\text { Bobot } \\
(\%)\end{array}$ & $\begin{array}{c}\text { Nilai } \\
\text { CAMEL }\end{array}$ \\
\hline 2014 & Permodalan & CAR & 95,55 & 100 & 25 & 25 \\
\cline { 2 - 7 } & $\begin{array}{l}\text { Kualitas aktiva } \\
\text { produktif }\end{array}$ & KAP & 2,54 & 87,4 & 30 & 11,99 \\
\cline { 2 - 7 } & Manajemen & NPM & 61,26 & 61,26 & 25 & 14,75 \\
\cline { 2 - 7 } & Rentabilitas & 1. ROA & 1,20 & 100 & 5 & 5 \\
\cline { 2 - 8 } & 2. BOPO & 82,72 & 100 & 5 & 5 \\
\cline { 2 - 8 } & Likuiditas & LDR & 38,44 & 100 & 10 & 10 \\
\hline \multirow{2}{*}{ Jumlah Nilai CAMEL 2014 } & 18,24 & 100 & 25 & 25 \\
\hline & Permodalan & CAR & $18,41,74$ \\
\cline { 2 - 8 } & $\begin{array}{l}\text { Kualitas aktiva } \\
\text { produktif }\end{array}$ & KAP & 3,45 & 81,33 & 30 & 11,47 \\
\cline { 2 - 8 } & Manajemen & NPM & 73,42 & 73,42 & 25 & 17,18 \\
\cline { 2 - 7 }
\end{tabular}

(C) 2020 STIE TDN. All rights reserved

Corresponding Author: 


\begin{tabular}{|c|c|c|c|c|c|c|}
\hline & \multirow[t]{2}{*}{ Rentabilitas } & IROA & 1,12 & 100 & 5 & 5 \\
\hline & & 2.BOPO & 78,00 & 100 & 5 & 5 \\
\hline & Likuiditas & LDR & 16,60 & 100 & 10 & 10 \\
\hline \multicolumn{6}{|c|}{ Jumlah Nilai CAMEL 2015} & 73,65 \\
\hline \multirow[t]{6}{*}{2016} & Permodalan & CAR I & 17,84 & 100 & 25 & 25 \\
\hline & $\begin{array}{l}\text { Kualitas aktiva } \\
\text { produktif }\end{array}$ & KAP & 2,22 & 89,53 & 30 & 12,17 \\
\hline & Manajemen & NPM & 79,45 & 79,45 & 25 & 18,39 \\
\hline & \multirow[t]{2}{*}{ Rentabilitas } & $1 . \mathrm{ROA}$ & 1,33 & 100 & 5 & 5 \\
\hline & & 2.BOPO & 70,10 & 100 & 5 & 5 \\
\hline & Likuiditas & LDR & 15,00 & 100 & 10 & 10 \\
\hline \multicolumn{6}{|c|}{ Jumlah Nilai CAMEL 2016} & 75,56 \\
\hline
\end{tabular}

\section{Sumber : Hasil Olahan Data}

Berdasarkan tabel. 8 yakni hasil perhitungan nilai ratio CAMEL, maka dapat disajikan hasil penilaian kesehatan dengan ratio CAMEL khususnya dalarn tahun 2014 s/d tahun 2016, yang dapat dilihat melalui tabel berikut ini:

Tabel. 9

Hasil Penilaian Tingkat Kesehatan Keuangan Bank Perkreditan Rakyat Hasamitra Cabang Makassar

Tahun 2013 s/d Tahun 2016

\begin{tabular}{|c|c|c|}
\hline Tahun & Nilai CAMEL & $\begin{array}{c}\text { Tingkat Kesehatan } \\
\text { Keuangan }\end{array}$ \\
\hline 2014 & 71,74 & Cukup Sehat \\
\hline 2015 & 73,65 & Cukup Sehat \\
\hline 2016 & 75,56 & Cukup Sehat \\
\hline
\end{tabular}

Sumber: Hasil Olahan Data

Pada tabel. 9 di atas menunjukan hasil perhitungan kesehatan keuangan untuk tiga tahun (tahun 2014 s/d tahun 2016) pada Bank Perkreditan Rakyat Hasamitra Cabang Makassar berada pada predikat Cukup Sehat.

\section{Pembahasan}

\section{Faktor Permodalan}

Salah satu faktor permodalan yang mempengaruhi kinerja keuangan khususnya bagi setiap perusahaan adalah faktor permodalan. Pentingnya aspek permodalan, maka salah satu rasio yang digunakan dalam mengukur kecukupan modal adalah rasio CAR (Capital Adequacy Ratio). Rasio CAR dapat dihitung dengan menggunakan rumus modal sendiri dibagi dengan aktiva tertimbang dikali seratus persen. Menurut ketentuan 
Bank Indonesia yang dinyatakan bahwa bank sehat jika, memiliki CAR paling sedikit sebesar delapan persen. Pada Bank Perkreditan Rakyat Hasamitra Cabang Makassar tahun yang diteliti yakm tahun2014 untuk modal sendiri 1.304.680 (dalam jutaan) dan aktiva tertimbang 1.365.396 (dalam jutaan) jumlah yang dimasukkan, setelah menggunakan rumus CAR yakni 0,9555 dikali seratus persen $95,55 \%$.Untuk tahun 2015 modal sendiri 1.950.000 (dalam jutaan) dan aktiva tertimbang 10.686.023 (dallam jutaan) jumlah yang dimasukkan setelah menggunakan rumus CAR yakni 0,1824 dikali seratus persen $18,24 \%$. Untuk tahun 2016 modal sendiri 2.215.658 (dalam jutaan) dan aktiva tertimbang 12.414 .816 (dalam jutaan) jumlah yang dimasukkan setelah menggunakan rumus CAR yakni 0,1784 dikali seratus persen 17,84\% Dari hasil perhitungan ratio CAR dapat pula peneliti menghitung nilai kredit CAR . Nilai kredit pada CAR yakni maksimum seratus. Untuk tahun 2013 nilai kredit CAR 956,5\%. Untuk tahun 2014 nilai kredit CAR 183,4\%. Untuk tahun 2015 nilai kredit CAR 1.79,4\%. Jadi untuk hasil perhitungan nilai rasio CAR mencapai diatas $8 \%$ sehingga pada faktor permodalan ini untuk Bank Perkreditan Rakyat Hasamitra, Cabang Makassar bisa dikatakan cukup sehat.

\section{Faktor Kualitas Aset}

Dalam perhitungan faktor kualitas aset, ratio yang digunakan adalah KAP (Kualitas Aktiva Produktif). Rasio ini merupakan perbandingan antara jumlah aktiva produktif yang diklasifikasikan dengan total aktiva produktif. Rumus untuk rasio KAP yakni aktiva produktif yang diklasifikasikan dibagi dengan total aktiva produktif Menurut ketentuan Bank Indonesia aktiva produktif yangdiklasifikasikan dapat diperhitungkan sebagai berikut. $0 \%$ dari kredit lancar, 25\% dari kredit yang dalam perhatian khusus, $50 \%$ dari kredit kurang lancar, 75\% dari kredit yang diragukan, $100 \%$ dari kredit macet. Pada Bank Perkreditan Rakyat Hasamitra. Cabang Makassar yang diteliti untuk tahun 2014 besarnya ratio KAP yakni 2,54\%. Untuk tahun 2015 besarnya rasio KAP yakni $3,45 \%$. Untuk tahun 2016 besarnya ratio KAP yakni $2,22 \%$. Dari hasil perhitungan nilai rasio KAP, peneliti juga dapat menghitung nilai kredit KAP. Besarnya nilai kredit rasio KAP untuk tahun 2014 yakni 87,4\%. Besamya nilai kredit rasio KAP. untuk tahun 2015 yakni $81,33 \%$.

\section{Faktor Manajemen}

Untuk menilai kesehatan bank dalam faktor manajemen, biasanya dilakukan melalui kuesioner yang ditujukan bagi pihak manajamen bank, akan tetapi pengisian tersebut sulit dilakukan karena akan terkait dengan unsur kerahasiaan bank. Jadi menurut Rhomy,2011 untuk penelitian aspek manajemen ini dapat diproyeksikan dengan menggunakan rasio net profit margin dengan rumus laba bersih dibagi dengan laba operasional dikali seratus persen. Pada Bank Perkreditan Rakyat Hasamitra Cabang Makassar untuk tahun 2014 Laba bersihnya 117.462.000 (dalam jutaan) dan laba operasionalnya 191.716 .000 (dalam jutaan). Jadi besarnya NTM pada tahun 2014 yakni 61,26\%. Untuk tahun 2015, laba bersih 163.251.000 (dalam jutaan) dan laba operasional 222.323.000 (dalam jutaan). Jadi besarnya NPM 
tahun 2014yakni 73,42\%. Untuk tahun 2016, laba bersih 228.525.000 (dalam jutaan) dan laba operasional 287.599.000 (dalam jutaan). Jadi besarnya rasio NPM untuk tahun 2016 yakni $74,45 \%$. Berdasarkan perhitungan rasio NPM terjadi peningkatan pada tahun 2015 yang disebabkan adanya kenaikan pada laba bersih. Tetapi pada tahun 2015 nilai rasio NPM mengalami penurunan sebesar 6,30\% . Menurut Rumhy,2011 bahwa dalam menentukan nilai CAMEL terlebih dahulu mengetahui nilai kredit yang dihasilkan rasio NPM. Tetapi karena aspek manajemen ini tidak bisa diteliti dengan menggunakan kuesioner sehingga di proyeksikan dengan menggunakan profit margin dengan pertumbuhan ratio ini menunjukan bagaimana manajemen mengolah sumber-sumber maupun alokasi penggunaan dana secara efisie, sehingga mlai rasio diperoleh langsung menjadi nilai kredit rasio NPM ini. Jadi nilai kredit rasio NPM untuk tahun 2014 yakni $61,26 \%$. Untuk tahun 2015 nilai kredit rasio NPM yakni 73,42\%. Dan tahun 2016 nilai kredit rasio NPM yakni 79,45\%

\section{Faktor Rentabilitas}

\section{a. Return On Asset (ROA)}

Untuk aspek rentabilatas ini menggunakan dua rasio yakni ROA dan BOPO. Penelitian ROA ini digunakan untuk mengukur kemampuan manajemen dalam memperoleh keuntungan. Semakin besar ROA semakin besar pula tingkat keuntungan yang dicapai bank, sehingga kemampuan suatu bank dalam suatu kondisibermasalah sangatlah kecil. Besarnya nilai ROA dapat dihitung dengan menggunakan rumus laba bersih sebelum pajak dibagi dengan total aktiva dikali seratus persen. Pada Bank Perkreditan Rakyat Hasamitra Cabang Makassar tahun 2014 untuk data laba bersih sebelum pajak 176.616 (dalam jutaan) dan total aktiva 14.708.504. Hasil ROA untuk tahun 2014 yakni 1,0\%. Untuk tahun 2015 data laba bersih sebelum pajak 220.133 (dalarn jutaan) dan total aktiva 19.492.112 (dalam jutaan). Jadi hasil ROA untuk tahun 2015 yakni $1,12 \%$. Untuk data tahun 2016 laba bersih sebelum pajak 307.768 (dalam jutaan) dan total aktiva 23.017.667 (dalam jutaan). Jadi besarnya ROA untuk tahun 2015 yakni $1,33 \%$. DariROA pada tahun 2014 mengalami penurunan. sebesar $-0,08 \%$ yang di karenakan pada total aktiva mengalami penurunan dari tahun 2014 ke tahun 2015. Dari Bank Indonesia menentukan bahwa batas minimum ROA yakni $1 \%$, apabila sebuah bank mempunyai ROA lebih besar dari $1,5 \%$ maka bank tersebut dapat dikatakan produktif mengelolah aktivitas keuangannya sehingga menghasilkan laba.

\section{b. BOPO}

Rasio BOPO ini digunakan mengukur tingkat efisiensi dan kemampuan bank dalam melakukan kegiatan operasinya. Rasio BOPO diperoleh dengan cara membagi Maya operasional, dengan menggunakan rumus beban operasional dibagi dengan pendapatan operasional dikali seratus persen. Pada Bank Perkreditan RakyatHasamitra Cabang Makassar untuk tahun 2014 data pendapatan operasional 1.061.877 (dalam jutaan) dan beban operasional 878.405 (dalam jutaan). Besarnya rasio BOPO untu tahun 2013 yakni $82,72 \%$. Untuk tahun 2015 data pendapatan operasional

(C) 2020 STIE TDN. All rights reserved 
1.435.051 (dalam jutaan) dan beban operasional 1.119.482 (dalam jutaan). Sehingga besarnya rasio BOPO untuk tahun 2015 yakni 78,00\%. Untuk tahun 2016 data pendapatan operasional 1.701.988 (dalam jutaan) dan beban operasional 1.193.136 (dalam jutaan). Jadi besarnya BOPO untuk tahun 2016 yakni $70,10 \%$. Pada rasio BOPO ini mengalami fluktuasi namun tidak begitu mempengaruhi penilaian terhadap nilai CAMEL.

\section{Faktor Likuiditas}

$\begin{array}{ccc}\text { Untuk } & \text { aspek } & \text { likuiditas ini } \\ \text { merupakan } & \text { untuk } & \text { mengukur }\end{array}$ kemampuan dalam memenuhi kewajiban-kewajiban jangka pendek atau kewajiban yang sudah jatuh tempo. Berdasarkan ketentuan yang dikeluarkan Bank Indonesia, komponen likuiditas bank diukur berdasarkan Loan to Deposit Ratio (LDR) dengan menggunakan rumus jumlah kredit yang diberikan dibagi dengan dana pihak ketiga dikali seratus persen. Pada Bank Perkreditan Rakyat Hasamitra Cabang Makassar untuk tahun 2014 data untuk jumlah kredit yang diberikan 4.391.790 (dalam jutaan) dan dana pihak ketiga 11.422.190 (dalam jutaan). Besamya rasio LDR untuk tahun 2014 yakni $38,44 \%$. Untuk tahun 2015 data jumlah kredit yang diberikan 2.698.064 (dalam jutaan) dan dana pihak ketiga 16.246.405 (dalam jutaan). Besarnya rasio LDR untuk tahun 2015 yakni $16,60 \%$. Untuk tahun 2016 data jumlah dana yang diberikan 2.898.935 (dalam jutaan) dan dana pihak ketiga 19.322.756 (dalam jutaan). Jadi besarnya nilai rasio LDR untuk tahun 2016 yakni 15,26\%. Nilai rasio pada Bank Perkreditan Rakyat Hasamitra Cabang Makassar untuk tahun 2014 s/d tahun 2016 mengalami tren fluktuasi. Hal ini dikarenakan bertumbuhnya kredit yang diberikan lebih besar dibandingkan penghimpun dana pihak ketiga.

\section{KESIMPULAN DAN SARAN Kesimpulan}

1. Berdasarkan analisis metode CAMEL Bank Perkreditan Rakyat Hasamitra Cabang Makassar tergolong bank yang berpredikat cukup sehat, dan memiliki kinerja yang baik dalam pengelolaan sumber dayanya yang dapat dilihat berdasarkan hasil perhitungan ratio CAMEL.

2. Bank Perkreditan Rakyat Hasamitra Cabang Makassar yang dapat dilihat dari hasil penilaian tingkat kesehatan atau nilai CAMELnya yang selama tiga tahun mengalami peningkatan setiap tahunnya.

\section{Saran}

Dari hasil simpulan yang sebagaimana telah diuraikan, maka akan diberikan beberapa saran-saran sebagai berikut :

1. Nilai kualitas aktiva produktif yang masih rendah dapat ditingkatkan dengan pemberian kredit kepada nasabah Bank Perkreditan Rakyat Hasamitra Cabang Makassar yang lebih ketat dalam artian bahwa kredit hanya diberikan pada nasabah yang benar-benar memegang teguh janjinya untuk melakukan kewajiban membayar kembali dana berikut bunganya.

2. Laporan keuangan bank seharusnya benar-benar diteliti

Corresponding Author: 
dan dianalisis untuk mengetahui secara detail kemampuan kinerja keuangan bank tanpa adanya manipulasi agar terhindar dari kebangkrutan atau financial distress.

\section{DAFTAR PUSTAKA}

Angkoso. 2006. Manajemen

Perkreditan.Penerbit. Air

Langga Persada. Jakarta.

Abdullah, M. Faisal. 2005. Manajemen Perbankan. Teknik Analisa Kinerja Keuangan.

Agus Malito (2005 : 51). Laporan Keuangan Bank. Penerbit. Raja Grafindo Persada. Jakarta.

Chariri, Ghozali. 2003. Analisa Laporan Keuangan. Penerbit. PT. Bumi Aksara Jakarta.

Dendawijaya, Lukman. 2009. Manajemen Perbankan. Penerbit. CV. Alfabeta. Bandung

Hasibuan, Melayu. 2007. Dasar-dasar Perbankan. Penerbit. PT. Bumi Aksara. Jakarta.

Harahap. 2005. Analisa Laporan Keuangan. Penerbit. PT. Raja Grafindo Persada. Jakarta

Hery. 2012. Analisa Laporan Keuangan. Penerbit. CAPS. Jakarta.
Jumingan. 2006. Laporan Keuangan. Penerbit. PT. Raja Grafindo Persada. Jakarta.

Iskandar. 2008. Manajemen Data Bank. Penerbit. PT. Raja Grafindo Persada. Jakarta.

Kasmir. 2008. Bank dan Lembaga Keuangan Lainnya. Penerbit. PT. Raja Grafindo Persada. Jakarta.

Leny, sulistiyowati. 2010. Panduan Praktik Memahami Laporan Keuangan. Penerbit Elex Media Komputindo. Jakarta.

Melayu. S.P. Hasibuan. 2007. Manajemen Perkreditan. Penerbit. Salemba Empat. Jakarta.

Martono. 2010. Manajemen Dana Bank. Penerbit. PT. Raja Grafindo Persada. Jakarta.

Mishkin, Frederic. 2008. Ekonomi Uang, Perbankan dan Pasar Keuangan. Salemba Empat. Jakarta.

Republik Indonesia. 1998. UndangUndang No. 10 Tahun 1998 tentang Perbankan.

Rifai. F. 2006. Credit Management Handbook. PT. Raja Grafindo Persada. Jakarta.

Ridwan, S. Sanjaya, 2003. Analisa Laporan Keuangan Perusahaan. Penerbit Salemba Empat. Jakarta. 
Syamsul, Iskandar. 2008. Manajemen Perbankan. Penerbit Salemba Empat. Jakarta.

Sugyono. 2008. Statistik Terapan Ekonomi. Penerbit PT. Raja Grafindo Persada. Jakarta.

Soemarso. 2005. Manajemen Perkreditan. Penerbit Air Langga. Jakarta.
Sutarno. 2003. Manajemen Perkreditan. Penerbit PT. Raja Grafindo Persada. Jakarta.

Tuanakotta. 2006. Manajemen Perbankan. Penerbit PT. Raja Grafindo Persada. Jakarta.

Taswan. 2008. Manajemen Dana Bank. Penerbit Salemba Empat. Jakarta. 